\title{
Has the European Union entered a bioeconomy transition? Combining an output-based approach with a shift-share analysis
}

\author{
Tévécia Ronzon ${ }^{1,2}$ (D) Susanne lost ${ }^{3} \cdot$ George Philippidis $^{4}$
}

Received: 3 March 2021 / Accepted: 19 August 2021 / Published online: 8 January 2022

(c) European Union, Thünen Institute and George Philippidis 2021

\begin{abstract}
The bioeconomy is a collective of activities charged with the production of biologically renewable resources or 'biomass' (e.g. agriculture, forestry), its diverse application (e.g. food, textiles, construction, chemicals) and subsequent reuse (e.g. compositing, waste management). Since the European Union (EU) launched its bioeconomy strategy in 2012, further bioeconomy policy initiatives have proliferated at regional, national and pan-European levels. Moreover, the EU Green Deal announced in 2019 targets a transition towards a low-carbon sustainable model of growth, food and energy security, biodiversity and natural resource management, where it is envisaged that the bioeconomy will play a key role. Despite a paucity of available data, the surge in policy interest has triggered the need for evidence-based monitoring of bioeconomy sectors and the efficient tailoring of policy support. Thus, on a Member State (MS) basis for the period 2008-2017, we (1) adopt an 'output-based' approach to construct a panel data of performance indicators and (2) characterise the sources of growth and transitional stage of the bioeconomy. Results reveal that the bioeconomy has maintained its relative importance within the total EU27 economy. At the EU level, agriculture and the food industry have played a key role in driving a transition in the primary and industrial bioeconomy sectors due to their significant labour productivity-enhancing impact. Four Northern MS exhibit a bioeconomy transition by modernising their bioeconomy activities and operating structural changes. Other Northern and Western EU MS are still in the early stages of a transition, whilst in Eastern and Central Europe, such a transition remains elusive.
\end{abstract}

Keywords Bioeconomy · Value added · Employment · Productivity · Structural change · Transition · Europe

Tévécia Ronzon

Tevecia.Ronzon@ec.europa.eu

1 European Commission, Joint Research Centre (JRC), Edificio Expo, Calle Inca Garcilaso, 3, 41092 Sevilla, Spain

2 Agricultural Economics and Rural Policy Group, Wageningen University, Wageningen, The Netherlands

3 Thünen Institute of International Forestry and Forest Economics, Hamburg, Germany

4 Centre for Agro-Food Research and, Technology (CITA), Aragonese Agency for Research and Development (ARAID), Agrifood Institute of Aragón (IA2), Government of Aragón, Zaragoza, Spain 


\section{Introduction}

The bioeconomy has emerged in the last decade as a new economic paradigm founded on the use and recycling of biological resources in place of fossil resources to help achieve multiple policy objectives relating to employment generation and growth, climate neutrality, food security, energy security, biodiversity and natural resource management (Wesseler $\&$ von Braun, 2017). To achieve these goals, governments have implemented bioeconomy strategies or similar policy initiatives targeting the different stages of traditional and emergent bio-based value chains.

For its part, the European Union (EU) launched its first bioeconomy strategy in 2012 to kickstart a transition towards a low-fossil economy whilst promoting job creation and competitiveness (European Commission, 2012). The second EU bioeconomy strategy, released in 2018, strengthens its territorial development and environmental objectives (European Commission, 2018; Kardung et al., 2021). Moreover, since 2012, the bioeconomy has been placed at the heart of several new EU political initiatives such as the Sustainable Development Goals (2015), the climate ambitions of the Paris Agreement (2015), the European Green Deal (2019) and the Circular Economy Action Plan launched in 2020. As further evidence of the rising strategic importance of the bioeconomy, nine EU Member States have publically released dedicated bioeconomy strategies, and in seven others they are under development. Macro-regional and micro-regional bioeconomy initiatives have also been launched (Lusser et al., 2018).

As the changing landscape has introduced the virtues of the bioeconomy into the mainstream of political thought, this has also unlocked greater business confidence (Gatto \& $\mathrm{Re}, 2021)$. Research and innovation target the ramping up of new biomass conversion processes, whilst industrial policy measures seek to bring bio-based innovations to market. On the demand side, despite the potential challenges (Sijtsema et al., 2016), consumer awareness campaigns, product labelling (Confente et al., 2020) and green public procurement initiatives (International Advisory Council on Global Bioeconomy, 2020) have sought to create high value market outlets for emerging bio-based products.

In tandem with the rise of the bioeconomy on the EU policy agenda, there is an urgent need for a transparent and consistent monitoring framework to assess the development of bioeconomy activities. The ambitions of this study are thus to (1) consolidate basic socio-economic indicators for the monitoring of the job and growth objectives of the EU bioeconomy and (2) to tentatively identify the drivers of bioeconomy growth in order to ultimately suggest policy options for realising the growth potential of EU Member States' bioeconomies. A key challenge facing objective (1) is the lack of official secondary data as bioeconomy activities are often subsumed within broad activity or product classifications.

Different methodologies that seek to disentangle bioeconomy activities from their respective parent industry classifications are discussed in the literature (e.g. Cingiz et al., 2021; M'Barek et al., 2018; Piotrowski et al., 2018). On the one hand, the 'input-based' approach measures the proportion of biomass in the inputs used for producing bio-based products and applies this proportion to value added or job statistics for that sector (Efken et al., 2016; Heijman, 2016; Iost et al., 2019; Kuosmanen et al., 2020; Meesters et al., 2013; Robert et al., 2020b). For example, in the input-based approach the food industry is only partially considered bio-based because it uses a mix of bio-based and fossil inputs, whilst under this criterion, even mining activities are 'part' bio-based. In contrast, the 'outputbased' approach measures the biomass content of the bio-based products of a given sector (Luke, 2019; Pellerin \& Taylor, 2008; Porc et al., 2020; Ronzon et al., 2020; Vandermeulen 
et al., 2011). Thus, under this classification, food industry activities are completely biobased since their output is fully (edible) biomass, whilst mining activities are not considered bio-based as the core output does not contain biomass.

In seeking to make a judgement on the choice of measurement method, we take a policy perspective. More specifically, biomass producing activities (i.e. agriculture, forestry, fishing and aquaculture), food and beverages and other bio-based sectors (i.e. wood, paper, textile and bioenergy products) are under the remit of the EU bioeconomy strategy. In contrast, mining activities, despite employing biomass inputs, are not. From this perspective, the output-based methodology is entirely consistent with the EU's bioeconomy strategy. Having taken the decision on the methodology of bioeconomy activity measurement, the output-based approach is also applied to quantify so-called hybrid sectors, which mix biobased and non-bio-based activities. As an insightful extension to the input-based approach, in their measurement of the bioeconomy Cingiz et al. (2021) also account for the influence of non-bio-based upstream industries sectors (e.g. financial, insurance, etc.) that provide inputs to bioeconomy sectors. Once again, however, since said upstream industries do not constitute part of the EU bioeconomy strategy, this approach is also discarded in favour of the output-based approach.

As a key novelty of our output-based approach, new data sources and calculation methods are proposed to quantify employment and value added in specific bio-based activities - such as waste management or construction-that were not addressed in previous studies (Porc et al., 2020; Ronzon et al., 2020). The resulting panel dataset comprises of 24 activities from the System of National Accounts (SNA) ${ }^{1}$ and covers the EU-27 (i.e. excluding the UK) over the period 2008-2017. The ratio of these two concepts is used to calculate labour productivity change for bio-based activities. The combination of value added, employment and productivity forms the basis of a further novel analytical step, namely to isolate sectoral and structural sources of labour productivity growth, which are central for the tailoring of bioeconomy policy measures.

In view of the concept of 'transition', progress is measured through changes in bioeconomy sectors' labour productivity. Furthermore to understand the structural basis motivating labour productivity in transition, two concepts are explored. On the one hand, we examine the premise that the modernisation and diversification of bio-based value chains arising from the adoption of new biomass conversion pathways, industrial renewal and growing markets for bio-based goods, should translate into labour productivity growth (i.e. intrasectoral or 'within-sector' effect). Secondly, the emergence and development of bio-based industries also implies 'structural change' resource reallocations (e.g. in this study represented by employment shifts) 'between-sectors', where such a reallocation generates labour productivity growth if resources are directed towards more productive activities ("productivity-enhancing') or vice-versa ('productivity-reducing').

To measure these concepts, a 'shift-share' analysis decomposes labour productivity into those stemming from 'within-sector' and 'structural change' effects. The shift-share methodology is commonly used in economic transition studies (de Vries et al., 2015; Dobrzanski \& Grabowski, 2019; Erumban et al., 2019; Kuusk et al., 2017; Moussir \& Chatri, 2020) and in development economics (McMillan et al., 2017). Given its parsimonious data requirements, it is particularly suited to monitor the bioeconomy as a case in point where

\footnotetext{
1 SNA activities are defined by the Statistical Classification of Economic Activities in the European Community (NACE) (Eurostat 2008).
} 
data scarcity prevents the use of more sophisticated econometric approaches (Havlik, 2015). ${ }^{2}$

Section 2 describes the methodological approach followed for the generation of panel data on value added, employment and labour productivity in bioeconomy sub-sectors in the EU and its Member States over the period 2008-2017. Section 3 is structured around three research questions: (1) Has the EU bioeconomy created jobs, economic growth and competitiveness? (Sect. 3.1), (2) What role did modernisation and structural change play in the EU bioeconomy transition? (Sect. 3.2), and (3) What were the sectorial sources of labour productivity gains in the EU bioeconomy (Sect. 3.3)? Section 4 highlights policy options according to the EU Member States' progress into the bioeconomy transition and acknowledges the interest of complementary indicators for the sustainability assessment of bioeconomy transitions. It also provides some reflections on the choice of methodology. Section 5 concludes.

\section{Methodology and data}

\subsection{Selection of bio-based sectors of activity}

Activities are reported according to the NACE classification in European statistics (see glossary in supplementary Information SI1), where the current study focuses on the primary (NACE sector A) and industrial bioeconomy (NACE sectors C to F) (hitherto referred to as 'the non-service bioeconomy'). Based on a literature review, the Horizon 2020 European project 'BioMonitor' has elaborated a list of NACE divisions that encompass biobased activities (Kardung et al., 2019, 2021). As a starting point, our study follows the BioMonitor list for those relevant activities in NACE sections A and $\mathrm{C}$ to F, although NACE division C19 is excluded and NACE divisions C18 and C32 are included. In the case of NACE C19 for 'manufacture of coke and refined petroleum products', whilst it employs bio-based materials, it only produces fossil-based outputs. It is therefore not considered as part of the bioeconomy. The NACE C18 classification for printing activities and NACE C32 that includes, among others, the manufacture of (wooden) toys and musical instruments, are considered as bio-based activities in the German bioeconomy monitoring system (Iost \& Weimar, 2020). Thus, although not included within the list of candidate sectors from the BioMonitor project, these activities were added to our bioeconomy definition.

The final detailed list of bio-based activities falling under the scope of this study is therefore as follows:

- biomass producing sectors: agriculture (A01), forestry (A02) and fishing and aquaculture (A03),

- the food, beverage and tobacco industries (C10-C12),

- the textile industry (C13-C15),

- the wood products $(\mathrm{C} 16)$, furniture $(\mathrm{C} 31)$, paper $(\mathrm{C} 17)$ and printing $(\mathrm{C} 18)$ industries,

- the chemical (C20), pharmaceutical (C21) and plastic (C22) industries,

\footnotetext{
${ }^{2}$ To further illustrate, the lack of data on bioeconomy capital resources obstructs the calculation of bioeconomy total factor productivity (Solow 1957).
} 
- the manufacture of other non-metallic mineral products (C23) and other manufacturing (C32),

- the water (E36), sewerage (E37) and waste (E38) collection and treatment as well as other waste management services (E39),

- the construction industry (F41-43).

\subsection{Computation of bio-based output shares for value added and employment}

Among the bio-based NACE divisions listed in the previous section, some activities are so broadly defined that they comprise of bio-based and non-bio-based components, which in some cases may even be rival technologies of the same end product. To extract a measure of bio-based activities only from the NACE official statistical divisions, it is necessary to determine the biomass content share $b_{n, c, y}$ - the bio-based output share-at the NACE 2-digit level $n$ and for each Member State $c$ and year $y(y=2008, \ldots, 2017)$. The biomass content ranges from $0 \%$ (the output of $n$ is not bio-based) to $100 \%$ (the output of $n$ is fully bio-based). When information is missing at the 2-digit NACE industry level $n$, bio-based output shares are determined at the NACE sub-level $m$ (NACE 3- or 4-digits code) and then aggregated up to the 2-digit level $n$ (see below). Thus, value added (VA) and employment $(E)$ bio-based shares are given as:

$$
\begin{aligned}
b_{n, c, y}^{V A} & =\frac{\sum_{m}\left(b_{m, c, y} \times V A_{m, c, y}\right)}{V A_{n, c, y}} \\
b_{n, c, y}^{E} & =\frac{\sum_{m}\left(b_{m, c, y} \times E_{m, c, y}\right)}{E_{n, c, y}}
\end{aligned}
$$

Note that when assuming NACE 2-digit bio-based output shares, both employment and value added share values are assumed the same. However, when aggregating up from NACE 3- or 4-digit classifications, because the employment distribution across activity sub-divisions ' $m$ ' differs from the corresponding value added distributions, this leads to different 2-digit ' $n$ ' bio-based output shares for employment and value added:

$$
\frac{\sum_{m}\left(b_{m, c, y} \times V A_{m, c, y}\right)}{V A_{n, c, y}} \neq \frac{\sum_{m}\left(b_{m, c, y} \times E_{m, c, y}\right)}{E_{n, c, y}}
$$

Thus, the 2-digit NACE biobased output share for value added and employment is $100 \%$ in the case of biomass producing activities ( $n=$ NACE divisions A01, A02, A03), the agrofood industry $(n=\mathrm{C} 10, \mathrm{C} 11, \mathrm{C} 12)$, water treatment $(n=\mathrm{E} 36)$ and sewerage $(n=\mathrm{E} 37)^{3}$ (green rows in Table 1).

For NACE divisions C13-C17 (manufacture of textiles, paper and wood products), C20-C22 (manufacture of chemicals, pharmaceuticals and plastics) and C31 (manufacture of furniture), we take the minimum and maximum bio-based output share $b_{n, c, y}$ from Ronzon et al. (2020) and Porc et al. (2020) (blue rows in Table 1). These studies define the biomass content of the products (8-digits Prodcom code) produced by the industries $\mathrm{C} 13-\mathrm{C} 17$,

\footnotetext{
3 The status of water as a bio-based product remains debated. Water is for example considered a biological resource and therefore 100\% bio-based in Finnish bioeconomy statistics (Luke, 2020).
} 
Table 1 Assumptions and data sources for the quantification of sectoral bio-based output shares, value added and number of people employed in the bioeconomy (sector $n$ or sub-sector $m$, country $c$, year $y$ )

\begin{tabular}{|c|c|c|}
\hline $\begin{array}{l}\text { NACE } \\
\text { division } \\
\text { codes }\end{array}$ & $\begin{array}{l}\text { Range of bio-based output share } s b_{n, c, y} \\
\text { or literature source } \\
\text { (' } n \text { ' denotes 2-digit NACE codes, ' } m \text { ' denotes 3- or 4- } \\
\text { digit NACE codes) }\end{array}$ & $\begin{array}{l}\text { Eurostat codes for value } \\
\text { added } V A_{n, c, y} \text { and } \\
\text { employment } E_{n} J_{n, c, y}\end{array}$ \\
\hline $\mathrm{A} 01-\mathrm{A} 03$ & $100 \%$ & $\begin{array}{l}\text { Eurostat nama_10_a64, } \\
\text { Eurostat nama_10_a64_e }\end{array}$ \\
\hline $\mathrm{C} 10-\mathrm{C} 12$ & $100 \%$ & Eurostat sbs_na_ind_r2 \\
\hline $\mathrm{C} 13-\mathrm{C} 17$ & $\begin{array}{l}\text { Eurostat Prom DS-066341, } \\
\text { Product bio-based shares from nova-Institute* }\end{array}$ & Eurostat sbs_na_ind_r2 \\
\hline C18 & $100 \%$ C1811, 0-100\% C1812- C1814 & Eurostat sbs_na_ind_r2 \\
\hline $\mathrm{C} 20-\mathrm{C} 22$ & $\begin{array}{l}\text { Eurostat Prom DS-066341, } \\
\text { Product bio-based shares from nova-Institute* }\end{array}$ & Eurostat sbs_na_ind_r2 \\
\hline $\mathrm{C} 23$ & $0-100 \%$ C2365 & Eurostat sbs_na_ind_r2 \\
\hline C31 & $\begin{array}{l}\text { Eurostat Prom DS-066341, } \\
\text { Product bio-based shares from nova-Institute* }\end{array}$ & Eurostat sbs_na_ind_r2 \\
\hline C32 & $0-100 \%$ C3212 and C3213 & Eurostat sbs_na_ind_r2 \\
\hline D35 & Eurostat nrg_bal_c (section 2.2) & Eurostat sbs_na_ind_r2 \\
\hline E36-E37 & $100 \%$ & Eurostat sbs_na_ind_r2 \\
\hline E38 & $\begin{array}{l}\text { Eurostat env_wasgen, Eurostat env_wastrt (section } \\
\text { 2.2) }\end{array}$ & Eurostat sbs_na_ind_r2 \\
\hline E39 & $0-100 \%$ & Eurostat sbs_na_ind_r2 \\
\hline $\mathrm{F} 41-\mathrm{F} 43$ & $\begin{array}{l}\text { Eurostat Prom DS-066341, Product bio-based shares } \\
\text { from nova*, 0-100\% missing Prom codes sect. } 2.2\end{array}$ & Eurostat sbs_na_con_r2 \\
\hline
\end{tabular}

*See Ronzon et al. (2020)

The NACE groups (3-digits NACE codes) and classes (4-digits NACE codes) that are not reported in the table do not belong to the bioeconomy

$b_{n, c, y}=100 \%$ in green rows, $b_{n, c, y}$ is taken from Ronzon et al. (2020) and Porc et al. (2020) in blue rows, $0 \%<b_{n, c, y}<100 \%$ in yellow rows (unavailable information) and $b_{n, c, y}$ is computed as explained in Sect. 2.2 in white rows. A glossary of NACE codes is provided in supplementary information section SI1

C20-C22 and C31. For each product, the multiplication of its production value by its biomass content share is an estimate of its bio-based production value (data from Eurostat, $2020 \mathrm{~g}$ ). At the industry level $n$, the sum of the bio-based production values over the total production value of that industry gives the bio-based output share $b_{n, c, y}$.

For NACE division D35 (energy production), $b_{n, c, y}$ is the proportion of bioenergy in total energy supply expressed in tonnes of oil equivalent as reported in Eurostat (2020c). Bioenergy supply is comprised of solid and liquid biofuels (R52 sub-codes), biogases (R5300), charcoal (R5160) and renewable municipal waste (W6210). In this case, the minimum $b_{n, c, y}$ is equal to the maximum $b_{n, c, y}$. 
For NACE division E38 (waste management), we assume that the biomass content of the wasted product is equivalent to the biomass content of the product itself. For example, the biomass content range of wasted textile is assumed equal to the biomass content range of textile (classification C13 above). Thus, the bio-based output share of the waste management industry (E38) is the sum of the bio-based content of wasted products estimated by type of waste from disaggregated waste statistics on waste generation (Eurostat, 2020d) and waste treatment (Eurostat, 2020h) (see supplementary Information SI2).

For NACE divisions F41-F43 (construction), the biobased output share is the proportion of biomass embedded in constructed buildings and civil engineering. Following the treatment of NACE divisions C13-C17, C20-C22 and C31, the biomass content of construction materials that remain in final constructed buildings and civil engineering ${ }^{4}$ (outputs) is defined at the product level. The sectoral bio-based output share for NACE division F41-F43 is the proportion of bio-based materials in total construction materials in value terms. The product list of remaining construction materials is derived from the $500^{+}$ Eurostat Prodcom products established by the Centre for Industrial Study and Cresme Ricerche (2017) for the European Construction Sector Observatory. ${ }^{5}$ Product biomass content ranges are taken from Ronzon et al. (2020) and Porc et al. (2020), or are otherwise assumed to be $0 \%$ bio-based. ${ }^{6}$ The value of bio-based materials is measured by their domestic sales as suggested by the European Construction Sector Observatory (Eurostat, $2020 \mathrm{~g}$ data).

Unfortunately, there is a lack of information on the biomass content on the output products of the remaining NACE divisions, namely, printing (C18), manufacturing of other non-metallic mineral products $(\mathrm{C} 23)$, other manufacturing $(\mathrm{C} 32)$ and remediation activities (E39) (yellow rows in Table 1). We therefore calculate time series values of value added and employment at the most disaggregated 3- or 4-digit NACE sectoral level ' $m$ ' $\left(E_{m, c, y}\right.$ and $\left.V A_{m, c, y}\right)$ by assuming some sub-activities as fully bio-based (i.e. $b_{m, c, y}=100 \%$ for the printing of newspapers of C1811), partly bio-based (i.e. $0 \%<b_{m, c, y}<100 \%$ for other printing activities and services C1812-C1814, the manufacture of fibre cement C2365, the manufacture of jewellery and imitations C3212-C3213, other waste management services E39) or completely non-bio-based (remaining NACE 4-digit C codes). Then, Eqs. (1) and (2) give the sectoral bio-based output shares for value added and employment.

Assumptions and data sources for the estimation of bio-based output shares are summarised in column 2 of Table 1 .

\subsection{Indicators and data sources}

The study computes the ratio of the number of people employed (variable ' $E$ ') to value added (variable ' $V A$ ') to infer a measure of labour productivity (variable ' $P$ ') (also called apparent labour productivity in Eurostat datasets). Within-sector labour productivity changes and structural changes are part of the shift-share analysis.

The computation of bio-based employment and value added by sector $n$, in country $c$ in year $y\left(E_{n, c, y}\right.$ and $V A_{n, c, y}$, respectively) is based on the multiplication of the bio-based

\footnotetext{
${ }^{4}$ For example, wooden shuttering for concrete, or equipment for scaffolding are not considered as an output of NACE section F because they do not remain in the final building.

5 https://ec.europa.eu/growth/sectors/construction/observatory_en

${ }^{6}$ Please see the list of bio-based and non-bio-based construction material in supplementary information section SI3.
} 
output share by activity, Member State and time period by panel data observations of employment and value added (in current prices) retrieved from the Eurostat structural business statistics and from the Eurostat national accounts for the available period 2008-2017 (column 3 of Table 1, Eurostat 2020a, b, e, f). Thus:

$$
V A_{n, c, y}=b_{n, c, y}^{V A} \times V A_{n, c, y}
$$

and

$$
E_{n, c, y}=b_{n, c, y}^{E} \times E_{n, c, y}
$$

It should be reminded that minimum-maximum ranges of bio-based output shares $b_{n, c, y}^{V A}$ and $b_{n, c, y}^{E}$ are determined in Sect. 2.2 to account for uncertainty. This therefore leads to the computation of minimum and maximum bio-based value added and employment estimates (see also Sect. 3).

The term $P_{n, c, y}$ refers to the value added generated per person employed given as:

$$
P_{n, c, y}=V A_{n, c, y} / E_{n, c, y}
$$

Location quotients (variable ' $L Q$ ') are also derived from employment data. For the nonservice bioeconomy (nsBE), the location quotient calculates the degree of labour concentration of each Member State $c$ in those activities that produce biomass or supply bio-based goods, proxied by each Member State's bioeconomy employment share compared with the corresponding figure for the EU27:

$$
L Q_{n s B E, c, y}=\frac{E_{n s B E, c, y} / E_{c, y}}{E_{n s B E, E U 27, y} / E_{E U 27, y}}
$$

The term $\Delta P_{n s B E, c, y}$ refers to non-service bioeconomy labour productivity changes. Following other studies (de Vries et al., 2015; Dobrzanski \& Grabowski, 2019; Erumban et al., 2019; Kuusk et al., 2017; McMillan et al., 2017; Moussir \& Chatri, 2020), it is decomposed into a 'within-sector' effect (first additive term) and a 'structural change' effect (second):

$$
\Delta P_{n s B E, c, y}=\sum_{n} S h E_{n, c, y 0} \Delta P_{n, c, y}+\sum_{n} P_{n, c, y} \Delta S h E_{n, c, y}
$$

where $S h E_{n, c, y}$ denotes the bioeconomy employment share of sector $n$ in Member State $c$. Thus, the within-sector effect is the employment share weighted sum of 'within-sector' productivity growth $\Delta P_{n, c, y}$. The structural change effect is the reallocation of bioeconomy employment between activities $n$ in Member State $c\left(\Delta S h E_{n, c, y}\right)$ weighted by the corresponding productivity levels, $P_{n, c, y}$.

Note that some authors further split the structural effect into 'static' and 'dynamic' effects as expressed in the second and third terms of the following equation (de Vries et al., 2015; Havlik, 2015; Kuusk et al., 2017):

$$
\Delta P_{c, y}=\sum_{n} \operatorname{Sh} E_{n, c, y 0} \Delta P_{n, c, y}+\sum_{n} P_{n, c, y} \Delta S h E_{n, c, y}+\sum_{n} \Delta P_{n, c, y} \Delta S h E_{n, c, y}
$$



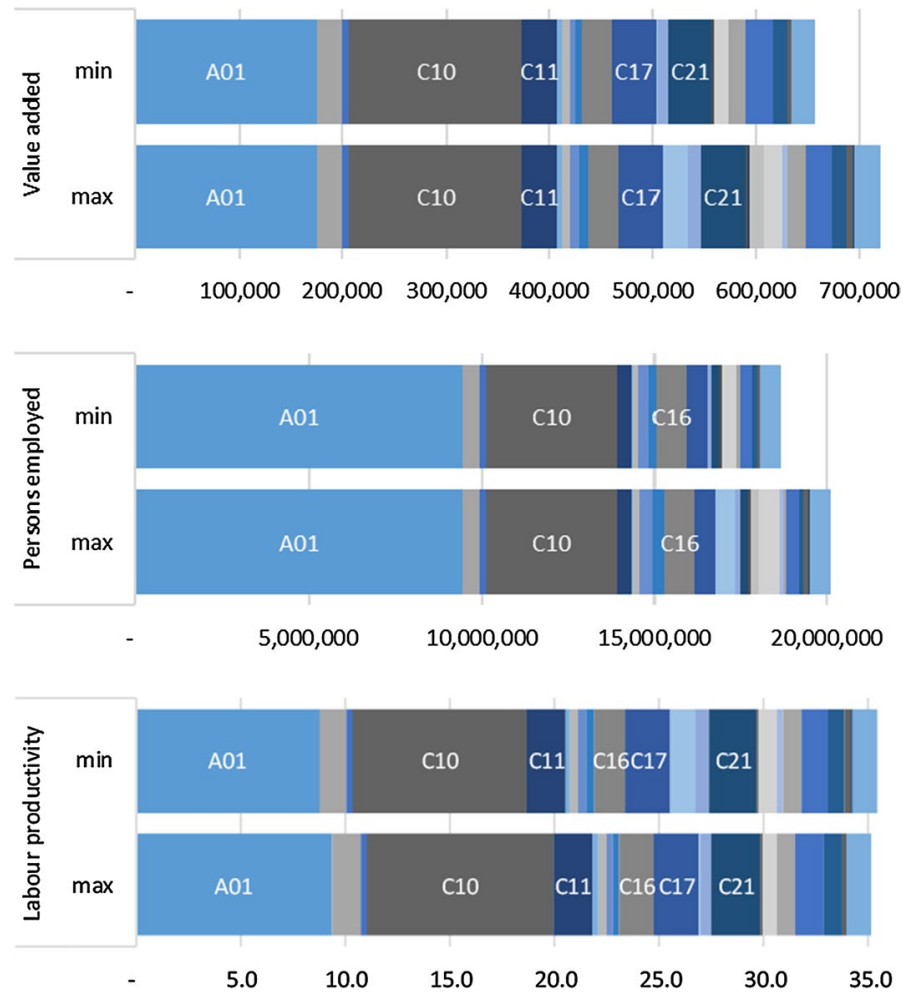

Fig. 1 Contribution of NACE activities to the non-service bioeconomy's value added ( $€$ million, top chart), number of persons employed (middle chart) and labour productivity ( $€$ thousand per person employed, bottom chart) (EU27, 3-year average for 2015-2017). Note: min (max) refers to the calculations derived from the minimum (maximum) bio-based output shares (see Sect. 2.2)

The interpretation of the three-component decomposition of labour productivity has been subject to debate. ${ }^{7}$ In this paper, we, therefore, analyse the two-component decomposition. It is complemented with an analysis of the individual sector contribution to aggregate productivity gains $S h E_{n, c, y 0} \Delta P_{n, c, y^{*}}$

\footnotetext{
${ }^{7}$ McMillan et al., (2017, p11) find difficulty interpreting the dynamic term 'when, for example, reductions in the employment share are accompanied by increases in productivity. This is because the term becomes negative, seemingly acting as a drag on productivity, when in fact it could be viewed as a positive development in such sectors as agriculture'.
} 


\section{Results}

\subsection{Has the EU non-service bioeconomy created jobs, economic growth and competitiveness?}

From our results, the value added of the European non-service bioeconomy has grown at a similar pace as the rest of the economy, maintaining a 6\% contribution to EU27 value added between 2008 and 2017 (not shown). Moreover, value added reached between $€ 657$ and $€ 706$ billion between the 2015 and 2017 period, half of which coming from agriculture (A01) and the food industry (C10) (three-year average, Fig. 1). The EU bioeconomy employed between 18.7 and 19.9 million workers in the 2015-2017 period, with more than the two-thirds coming from agriculture (A01) and the food industry (C10) (three-year average, Fig. 1). However, largely due to the restructuring of the EU agriculture sector, between 2008-2010 and 2015-2017, the employment base has reduced by around 2 million workers (of which -1.7 million are agriculture workers). As a result, the European non-service bioeconomy has struggled to maintain its share of total employment over the observed period.

Our dataset does not allow us to observe the price competitiveness of European biobased products, but it does indicate labour productivity gains of $€ 7,100-€ 8,000$ per worker in the non-service bioeconomy between 2008-2010 and 2015-2017 (not shown). In 2015-2017, agriculture and the food industry both contribute approximately $24-26 \%$ to aggregate labour productivity in the non-service bioeconomy and could have played a significant role in this evolution. The manufacture of beverages (C11), paper (C17), wooden furniture $(\mathrm{C} 16)$ and bio-based pharmaceuticals $(\mathrm{C} 21)$ each generates labour productivity contributions of $4.5-6.5 \%$ (Fig. 1).

It is important to note that labour productivity developments were very uneven across the EU27. Major gains occurred in Denmark, Ireland and Belgium ( $>€ 20,000$ per person employed between 2008-2010 and 2015-2017), Finland ( $>€ 19,000$ per person), the Netherlands, Austria and Sweden ( $>€ 10,000$ per person), whilst Greece was the only Member State experiencing a reduction in aggregate labour productivity of its non-service bioeconomy $^{8}$ ( $y$-axis of Fig. 2).

Although this study extends the sector coverage of Ronzon et al. (2020) to all non-service bioeconomy sectors, we observe the same grouping of countries as that study (Fig. 2). A dynamic representation of the scatter plot reveals variations in the level of labour concentration of national economies in the non-service bioeconomy in Eastern Member States and Greece (green group), whilst it remains almost unchanged in the other EU Member States between 2008-2010 and 2015-2017 (arrows in Fig. 2, x-axis variations). At the same time, labour productivity has dramatically increased in the Western and Northern Member States (orange and red groups, $y$-axis variations).

\footnotetext{
${ }^{8}$ Greece has perhaps been the EU Member State most acutely affected by the 2008-2009 financial crisis. The European Court of Auditors attributed the vulnerability of the Greek economy at that time to 'growing macroeconomic imbalances, large stocks of public and external debt, weak external competitiveness, an unsustainable pension system and weak institutions' (European Court of Auditors 2017, page 7). In a report to the European Commission, Rodríguez-Pose and Ganau (2019) add that population ageing, the rigid labour market and the possible low level of institutional quality are additional causes of poor labour productivity in Greece (2003-2015). They define a low level of institutional quality by a lack of transparency and accountability, corruption, and poor governance performance.
} 


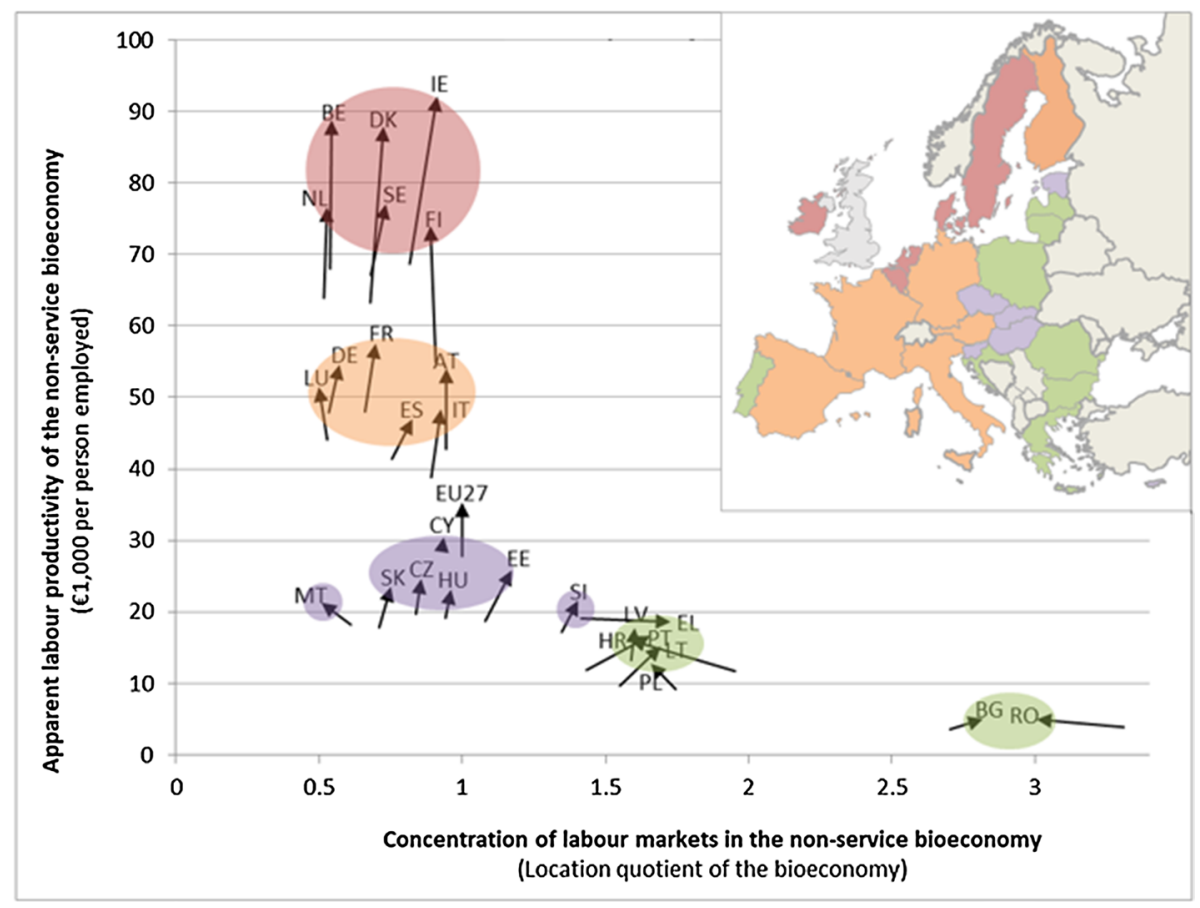

Fig. 2 Evolution of the location quotient and apparent labour productivity in the non-service bioeconomy of the 27 EU Member States between 2008-2010 and 2015-2017 (average estimates).

Note: The coloured circle indicates four groups of Member States: (1) Green group: Eastern Member States, Portugal, and Greece characterised by a labour market highly specialised in the non-service bioeconomy $\left(1.5 \leq L Q_{n s B E, c}\right)$ and a below-average apparent labour productivity of the non-service bioeconomy $\left(P_{n s B E, c} \leq 1 / 2 P_{n S B E, \mathrm{EU} 27}\right)$; (2) Purple group: Estonia and Central Member States, less specialised in the nonservice bioeconomy, but more labour productive $\left(L Q_{n s B E, c} \leq 1.4\right.$ and $\left.1 / 2 P_{n s B E, \text { EU27 }} \leq P_{n s B E, c} \leq P_{n s B E, \text { EU27 }}\right)$; (3) Orange group: Western Member States with exacerbated characteristics compared to the purple group $\left(L Q_{n s B E, c} \leq 0.9\right.$ and $\left.P_{n s B E, \mathrm{EU} 27} \leq P_{n s B E, c}\right)$, (4) Red group: Northern Member States with even higher labour productivity $\left(L Q_{n s B E, c} \leq 0.9\right.$ and $\left.2 . P_{n s B E, \mathrm{EU} 27} \leq P_{n s B E, c}\right)$. The EU27 Member States are represented by their official country code: Austria (AT), Belgium (BE), Bulgaria (BG), Croatia (HR), Cyprus (CY), Czechia (CZ), Denmark (DK), Estonia (EE), Finland (FI), France (FR), Germany (DE), Greece (EL), Hungary (HU), Ireland (IE), Italy (IT), Latvia (LV), Lithuania (LT), Luxembourg (LU), Malta (MT), Netherlands (NL), Poland (PL), Portugal (PT), Romania (RO), Slovakia (SK), Slovenia (SI), Spain (ES) and Sweden (SE)

In sum, the non-service bioeconomy has maintained its position within the total EU27 economy and total labour force over the period 2008-2017 by creating net value added but no net jobs. This entailed growth in labour productivity, especially in Northern and Western EU Member States. Agriculture and the food industry are preponderant in the sectoral structure of the non-service bioeconomy, and their intra-dynamics are likely to have influenced the whole aggregate of non-service bioeconomy. The next section will look at the nature of labour productivity developments and verify whether they are related to the grouping of countries observed in Fig. 2. 


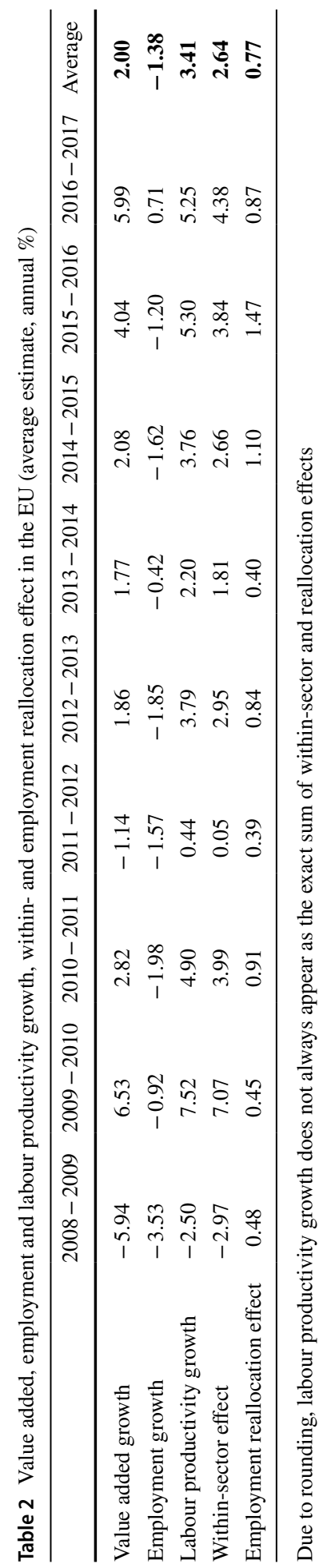




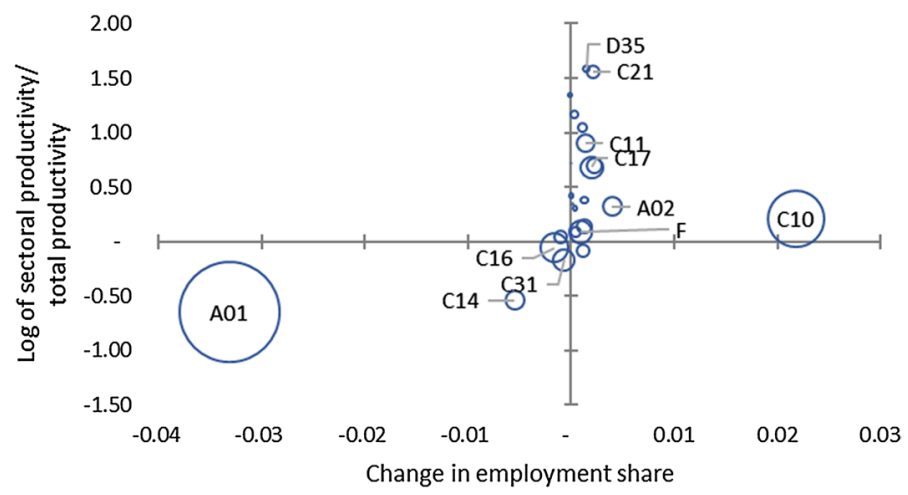

Fig. 3 Sectoral productivity and change in employment share in the EU, 2008-2017 (average estimates, a figure based on McMillan and Rodrik (2011)).

Note: Size of circle represents employment share in 2008-2010. The change in employment share is calculated on the 3-year average 2008-2010 to 2015-2017. The log of the productivity share is calculated at the end of the period (i.e. 2015-2017 average)

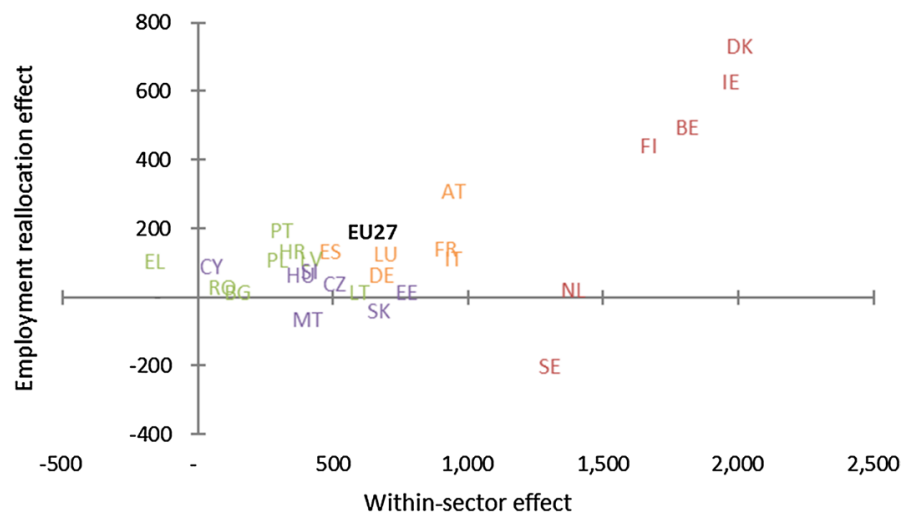

Fig. 4 Distribution of the EU Member States according to the within-sector and employment reallocation components of the aggregate labour productivity gains experienced by the non-service bioeconomy between 2008-2010 and 2015-2017 (Euros per person employed and per annum, average estimates)

\subsection{What role did modernisation and structural change play in the EU non-service bioeconomy transition?}

Table 2 presents the decomposition of EU non-service bioeconomy labour productivity growth into within-sector and employment reallocation (or structural change) effects following Eq. (8). Excluding the 2008-2009 crisis period, both within-sector and employment reallocation effects were productivity-enhancing (positive sign). The within-sector labour productivity growth largely predominated, varying between 0 and 7 per cent per annum. In comparison, the reallocation of workers across bioeconomy sectors triggered less than 1.5 per cent growth per annum which indicates that, to a certain extent, bioeconomy workers have moved from low- to high-productivity activities on average. The preponderance 


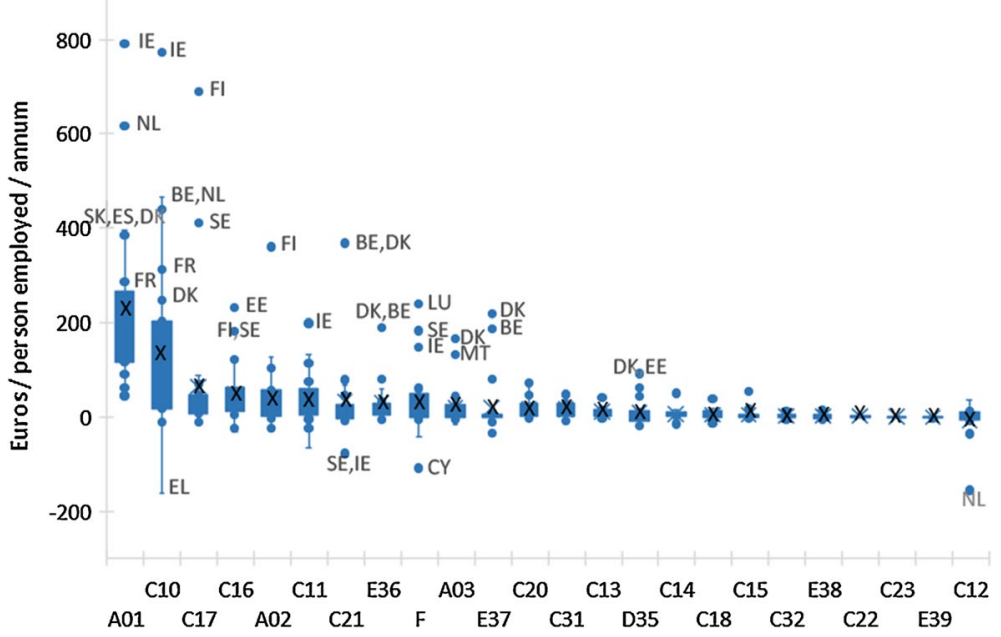

Fig. 5 Annual within-sector effect on labour productivity variation $\Delta P_{n, c, y}$ between 2008-2010 and 20152017 (average estimates, sectors ranked by descending order of the average within-sector effect across the Member States).

Note: For each sector $n, \mathrm{X}$ indicates the mean, the lowest part of the box indicates the 2nd quartile and the upper part the 3rd, the low and high whiskers the 1st and 4th quartiles; outliers are shown with dots and country code

of within-sector effects is consistent with observations made on macroeconomies ${ }^{9}$ (Fagerberg, 2000; Kuusk et al., 2017; Peneder, 2003; Timmer \& Szirmai, 2000).

For the EU as a whole, agriculture and the food industry played a significant productivity-enhancing role (Fig. 3). On the one hand, employment significantly contracted in agriculture (x-axis), the largest employing sector and also the least labour productive sector of the EU non-service bioeconomy ( $y$-axis). On the other hand, the most significant increase in employment share happened in the food industry, also characterised by above-average productivity. The production of bioenergy (D35) and the manufacturing of bio-based pharmaceuticals (C21) appear to be the most labour productive sectors of the non-service bioeconomy, but their pull effect on aggregate labour productivity has been less significant due to their relatively small employment base (size of the circles).

A closer look at the Member States' dynamics reveals common traits in the productivity drivers (Fig. 4). The Member States of the red group from Fig. 2 (in red lettering in Fig. 4), experience the highest within-sector productivity gains by some distance ( $>€ 1,300$ per worker per year). Such gains were accompanied by important productivity-enhancing structural effects in the case of four countries out of these six (Belgium, Denmark, Finland and Ireland with annual productivity gains due to employment reallocation higher than $€ 440$ per worker). In the Netherlands, employment reallocation hardly affects aggregate labour productivity of the non-service bioeconomy. In Sweden, workers appear to have moved to lower-productivity sectors (structural change effect of $-€ 200$ euros per workers per year).

\footnotetext{
${ }^{9}$ With the exception of the shift-share analysis by Dobrzanski and Grabowski (2019) on Central and Eastern European Member States over the period 2004-2018 that shows a dominant role for structural change effects on labour productivity growth.
} 
Those Member States in the orange group from Fig. 2 (in orange lettering in Fig. 4) occupy an intermediate position. They experienced gains in within-sector labour productivity higher than the EU-27 level ( $>€ 650$ per worker per year, except for Spain), whilst the positive effect of employment reallocation on aggregate labour productivity was below the EU effect ( $<€ 190$ per worker per year).

The Member States of the purple and green group experienced low-to-medium within-sector labour productivity gains (ranging from negative productivity changes in Greece to slightly above-EU level in Estonia and Slovakia) and negative-to-low employment reallocation effects (negative in the case of Malta and Slovakia, to almost equal to the EU level in the case of Portugal).

\subsection{How did sectorial labour productivity gains contribute to the EU non-service bioeconomy transition?}

For each Member State in Fig. 5, the within-sector contribution to variations of the aggregate labour productivity of the non-service bioeconomy is plotted by NACE sector in Fig. 5. Not surprisingly, major contributions came from agriculture (A01) and the food industry $(\mathrm{C} 10)$ which on average triggered aggregate productivity gains of $€ 220$ and $€ 130$ per worker per annum respectively (crosses in Fig. 5). They are followed by the manufacture of paper $(\mathrm{C} 17)$ and of wood products $(\mathrm{C} 16)$ ( $€ 65$ and $€ 50$ per worker per annum). Forestry (A02), the manufacture of beverages (C11), bio-based pharmaceuticals (C21), water management (E36) and the construction sector contributed to elevating the aggregate productivity in the order of $€ 30-€ 37$ euros per worker per annum. The remaining non-service bioeconomy sectors showed a lower average contribution.

A number of outliers stress national specificities. Agriculture in Ireland and the Netherlands, the Irish food industry and Finnish paper manufacture were major engines of bioeconomy growth, steering their bioeconomy's aggregate labour productivity by more than $€ 600$ per worker per year. The within-sector effects on the food industry in Belgium and the Netherlands and Swedish paper manufacture were also notable (above $€ 400$ per worker per year), closely followed by the within-sector effect of agriculture in Denmark, Spain and Slovakia, the manufacture of bio-based pharmaceuticals in Belgium and Denmark as well as the Finnish forestry sector (between $€ 360$ and $€ 395$ per worker per year).

Outliers also identify cases of within-sector effects that reduce productivity, such as in the case of the Greek food industry (C10), Dutch manufacturing of tobacco (C12) and the Cypriot construction sector $(\mathrm{F})$ that pulled down their respective bioeconomy labour productivity by more than $€ 100$ per worker per year. The Swedish and Irish manufacture of bio-based chemicals also caused annual productivity losses in the order of $€ 66$ to $€ 77$ per worker.

\section{Discussion and caveats}

\subsection{Bioeconomy transition stages in EU member states}

In the field of development economics, McMillan et al. (2017) distinguish sectoral and transversal policies. Sectoral policies aim at moving resources into specific (often 
'modern') industries by the means of subsidies, investment incentives or by removing specific obstacles. They usually strengthen the 'private fundamentals' (Atolia et al., 2020) that are physical capital, technology, knowledge-skills and the innovation endowment of the targeted industries. Transversal policies aim at developing broad capabilities by investing in 'public fundamentals' (Atolia et al., 2020) that are human capital, institutions and infrastructures. Whilst sectoral policies can entail both within-sector and sectoral labour productivity growth, Atolia et al. (2020) observe from developing countries' growth trajectories that 'public fundamentals play a relatively more important role than private fundamentals in the initial jump-starting of structural transformation and economic growth'. Borrowing these concepts from development economics sheds light on different policy needs in EU Member States for realising their bioeconomy growth potential.

First of all, according to our results, the non-service bioeconomy of Belgium, Denmark, Finland and Ireland is among the most labour productive in Europe and has exhibited impressive within-sector and structural labour productivity gains over the last decade. This suggests that the right conditions (public and private fundamentals) were in place for these countries to transit towards a bioeconomy. Interestingly, all four bioeconomies are governed by either a national or a regional strategy.

Secondly, the non-service bioeconomy of the other Member States of the Northern and Western groups of countries identified at Fig. 2 (Austria, France, Germany, Italy, Luxembourg, Netherlands, Spain and Sweden) is also highly labour productive but has only shown more moderate aggregate labour productivity gains. In particular, the structural labour change effects on aggregate productivity gains have been rather weak. All these countries-except Luxembourg-have a national or a macro-regional bioeconomy strategy in place. Sectoral measures may well have been successful at modernising their biobased industries and rising their within-sector labour productivity. Notwithstanding, the soft structural change effect suggests that the bioeconomy transition is still at its early stage and could be boosted by supports to new bio-based industries and to public fundamentals.

Finally, in the rest of the EU Member States (Bulgaria, Croatia, Cyprus, Czechia, Estonia, Greece, Hungary, Latvia, Lithuania, Malta, Poland, Portugal, Romania, Slovenia, Slovakia), the non-service bioeconomy has achieved below-EU average labour productivity levels. Within-sector and structural labour change effects are also mostly below-EU average. Within these countries only Latvia has a national bioeconomy strategy in place, whilst most of the other countries are in the process of designing their own. Our results suggest that both sectoral and transversal measures have to be mobilised in future bioeconomy strategies to engage them in a bioeconomy transition. The sectoral labour productivity differentials with the Northern and Western Member States indeed indicate a large potential for bioeconomy developments, and sector-specific measures could help to bridge these gaps whilst favouring structural changes at the same time. The identification of productivity enhancing/reducing within-sector effects in Sect. 3.3 is important evidence for such a tailoring of future bioeconomy policy instruments.

\subsection{Economic transition and sustainable bioeconomy transition}

Whilst our study touches on the economic (value added indicator) and social (employment indicator) dimensions of the bioeconomy, sustainability is a complex and pluri-dimensional concept. As an example, the internationally agreed framework of the sustainable 
Calculated on value added

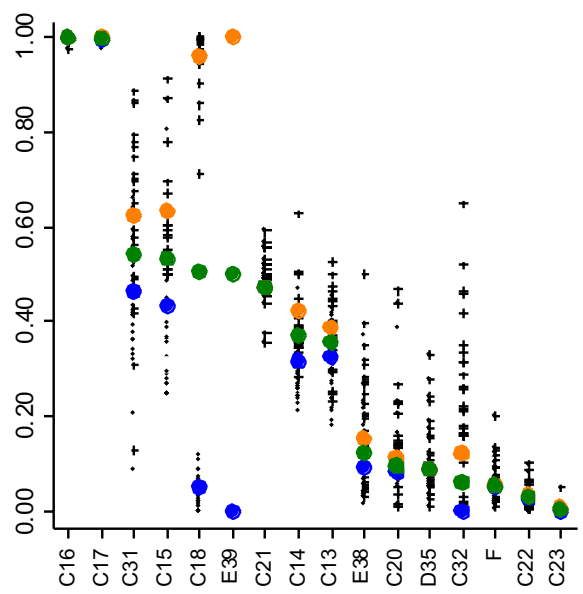

Calculated on persons employed

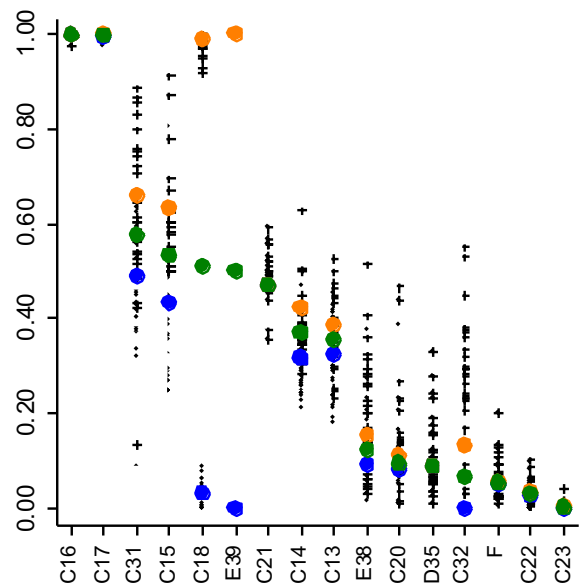

$$
\begin{array}{ll}
\cdot \min M S & +\operatorname{maxMS} \\
-\min E U 27 & \operatorname{maxEU} 27 \\
\operatorname{av} E U 27 &
\end{array}
$$

Fig. 6 Range of the NACE 2-digit bio-based output shares quantified from value added data (left) and employment data (right) for the EU27 (2015-2017), and their distribution across EU Member States.

Note: Large dots represent min, average and max bio-based shares for the EU. The distribution of the bioeconomy orientation of a given sector within the 27 EU Member States is represented by the '- ' (minimum bio-based share) and '+' (maximum share) points on the figures. For example, whilst the EU min-max range is relatively narrow for the bio-based chemical sector (C20), the bio-based output share of that sector varies from 0 to nearly $50 \%$ in Member States

development goals (SDGs) considers seventeen dimensions, measured with $360+$ indicators. ${ }^{10}$ However, ecological economists prioritise the ecological dimension pointing out that any human activity is constrained by the biosphere, thereby positioning its resilience as a sine quae non condition for sustainable human-driven development (Folke et al., 2016; Griggs et al., 2013). The quantification of planetary boundaries and of a safe operating space for humanity provides a concrete theoretical framework to assess sustainable human development (Rockström et al., 2009; Steffen et al., 2015).

Also looking at the preservation of natural capital, bioeconomy concepts/visions are often analysed in the literature according to their position between a weak and a strong sustainability paradigm. The weak sustainability paradigm assumes that the deterioration of natural capital can be offset by technological progress, as opposed to the strong sustainability paradigm that advocates the strict preservation of unsubstitutable natural capital and an absolute decoupling with economic growth (Neumayer, 2003 in Bennich \& Belyazid, 2017). Bennich and Belyazid (2017), D’Amato et al. (2017), Meyer (2017), Bugge et al. (2016) and Ramcilovic-Suominen and Pülzl (2018) observe that general bioeconomy concepts or the bioeconomy vision defined in the first bioeconomy strategy of the European Union lean towards a weak sustainability paradigm, giving little attention to decoupling

$\overline{{ }^{10} \text { https://unstats.un.org/sdgs/indicators/database/ }}$ 
bioeconomic growth from the risks of deforestation, loss of biodiversity, land use change and deterioration of water, soil and air. The revision of the EU bioeconomy strategy in 2018 acknowledges such potential risks and makes greater emphasis on the ecological and social base of the bioeconomy with one pillar out of three dedicated to 'understanding the ecological boundaries of the bioeconomy' and a further pillar dedicated to a fair territorial deployment of the bioeconomy in the EU.

In pursuing strong sustainability objectives, Liobikiene et al. (2019) also suggest monitoring the ability of the European bioeconomy in limiting resource 'leakage effects' using the indicators of the land footprint and land biocapacity (i.e. the landfootprint of the bioeconomy should not exceed the biocapacity). Quantifying these indicators for the EU Member States, Liobikiene et al. (2020) find that the land biocapacity of the bioeconomy is almost achieved in Estonia and Denmark and already exceeded in Belgium (purple and red groups of countries). On the other hand, almost $30 \%$ of the biocapacity of the land biocapacity of Croatia, Slovenia, Slovakia and Romania remained un-exploited in 2013 (green and purple groups of countries).

Bringezu et al. (2021) extend the measure of the German bioeconomy footprint to agriculture and forestry biomass footprints, agriculture land footprint, climate footprint, water footprint, as well as value added and employment footprint. These recent works will feed the on-going design and implementation of a European bioeconomy monitoring system by the European Commission that embraces the multiple dimensions of sustainability (Robert et al., 2020a).

\subsection{Caveats of the study}

The principal limitation of the study lies in the determination of bio-based output shares $b_{n, c, y}$ for the NACE divisions where there are issues of data scarcity relating to biomass content estimates. As a result, uncertainty was acknowledged with a range of $0 \%$ to $100 \%$ bio-based output share in the case of 'remediation activities and other waste management services' (E39) and for the sub-activities C1811, C1812, C1813, C1814, C2365, C3212 and C3213 (Sect. 2.3 and Table 1). This resulted in a particularly wide range of bio-based output share values at the NACE division level for the printing industry (C18) and remediation activities (E39) (Fig. 6). The accumulation of uncertainties at the NACE division and the country level led to an uncertainty interval in the calculation of EU non-servicerelated bioeconomy value added of $€ 49$ billion between total lower and upper thresholds of $€ 657$ and $€ 706$ billion, respectively. Similarly, the bioeconomy employment uncertainty interval is 1.2 million workers, between the total lower and upper thresholds of 18.7 to 19.9 million. Finally, the uncertainty interval for apparent labour productivity is $€ 300$ euros of value added per worker, with an absolute range of between $€ 35,200$ to $€ 35,500$ euros per worker.

The labour productivity developments observed in this study to 2017 could be interpreted as partial short-/medium-term effects of the EU bioeconomy strategy launched in 2012; however, our study does not conclude on causality effects. The time span of the study is restricted by the availability of biobased output share estimates for products manufactured by industries $\mathrm{C} 13-\mathrm{C} 17, \mathrm{C} 20-\mathrm{C} 22$ and C31. These share estimates are currently being updated by Porc et al. (2020), thereby offering, in tandem with readily available Eurostat annual observations, an opportunity to extend the time series beyond 2017. 
Another limitation of the analysis of the motors of productivity growth within the nonservice bioeconomy sectors relates to data scarcity on the factors of productivity other than employment and value added. A time series of data on investments (capital factors), labour skill types or levels of education (human capital) and technical change would have allowed a more detailed analysis and estimation of total factor productivity (McMillan et al., 2017; Timmer \& Szirmai, 2000).

\section{Conclusion}

Currently, there is a general paucity of data available from respected secondary data sources for supporting the monitoring and evaluation of the performance of the EU bioeconomy (Robert et al., 2020a). This paper represents an attempt to bridge that gap by employing varied sources, assumptions and data analysis techniques to examine the patterns of productivity growth and transition in the bioeconomy of the EU and its 27 Member States. This research also responds to the need to inform the policy debate on the design and targeting of green growth sustainable investment strategies akin to the EU's 'green list' or Taxonomy under the auspices of the Green Deal (European Union 2020).

We find that the non-service bioeconomy has maintained its position within the total EU27 economy and labour force over the period 2008-2017, by creating net value added but no net jobs. With the exception of Greece that was acutely affected by the 2008-2009 crisis, bioeconomy labour productivity growth has ensued in all Member States. Agriculture and the food industry are preponderant in the sectoral structure of the non-service European bioeconomy and have played a significant labour productivity-enhancing role at the EU level. On the one hand, employment significantly contracted in agriculture, the largest employer and the least labour productive sector of the EU non-service bioeconomy. On the other hand, the most significant increase in employment share happened in the food industry, characterised by above-average productivity.

At the national level, Belgium, Denmark, Finland and Ireland exhibit a bioeconomy transition by modernising their bioeconomy activities and mobilising structural changes. Other Northern and Western EU Member States are still in the early stages of a transition. The modernisation of certain bio-based industries has brought consequent labour productivity gains, although signs of employment reallocation towards emerging bio-based industries remain weak. Finally, a large potential for sectoral labour productivity improvements is identified in Eastern and Central Europe, where the design and implementation of bioeconomy strategies could kickstart a bioeconomy transition.

As the policy focus in Europe (and elsewhere) continues to reconcile market and nonmarket policy objectives of sustainable growth, the bioeconomy will continue to play a pivotal role. Looking forward, it is perhaps premature to make reasoned judgements on the degree of resilience of the bioeconomy to the current COVID pandemic and the concomitant impact on the stability of the supply chains. Indeed, an interesting hypothesis to test in future research of this type would be the presence of bioeconomy productivity improvements through proposed improvements in research and development and digitalisation driven by the EU's $€ 1.8$ trillion recovery plan.

Finally, the economic analysis proposed in this study can only be considered as a very partial contribution to any effort of bioeconomy monitoring or to the assessment of bioeconomy transitions. As the updated bioeconomy strategy of the European Union recalls, the bioeconomy is not sustainable per se, and the jobs and growth objectives of the strategy 
have to be obtained together with a fair redistribution of the benefits of bioeconomy developments and within the ecological boundaries of our planet. Our study also highlights important data gaps for computing additional socio-economic indicators, which for certain dimensions of bioeconomy development remain challenging (environmental, biophysical, innovation, skills, etc.). Beyond the data basis, transdisciplinary approaches require urgent attention to generate a balanced assessment of bioeconomy transitions. The progressive implementation of a Bioeconomy Monitoring System by the European Commission as well as funding attributed to research and innovation in the field of bioeconomy within the Horizon Europe framework programmes will support such avenues.

Supplementary Information The online version contains supplementary material available at https://doi. org/10.1007/s 10668-021-01780-8.

Acknowledgements The authors would like to thank the reviewers for their feedback on earlier drafts of the paper, as well as Robert M'barek, the leader of the bioeconomy team in unit D.4. at the JRC unit Economics of Agriculture, and his team. We would also like to thank Natalia and Timo Kuosmamen for helpful discussions on the input- and output-based methodologies. We are also very grateful to our partners from the H2020 project BioMonitor and in particular Dusan Drabik, Justus Wesseler and Myrna van Leeuven who all offered very useful insights on earlier drafts of the paper.

Funding This work was partially supported by the European Commission [Administrative Arrangement No. JRC 34488-2016] and the H2020 BioMonitor project [grant agreement No. 773297]. Partial support was also received from Instituto Nacional de Investigación y Tecnología Agraria y Alimentaria (INIA) (RTA2017-00046-00-00), co-funded by FEDER 'Operational Program Smart-Growth' 2014-2020, for the project 'Bioeconomía 2030: Un análisis cuantitativo de las perspectivas a medio plazo en España'.

\section{Declarations}

Conflict of interest The authors declare that they have no known competing financial interests or personal relationships that could have appeared to influence the work reported in this paper. The views expressed are those solely of the authors and should not in any circumstances be regarded as stating an official position of the European Commission.

Open Access This article is licensed under a Creative Commons Attribution 4.0 International License, which permits use, sharing, adaptation, distribution and reproduction in any medium or format, as long as you give appropriate credit to the original author(s) and the source, provide a link to the Creative Commons licence, and indicate if changes were made. The images or other third party material in this article are included in the article's Creative Commons licence, unless indicated otherwise in a credit line to the material. If material is not included in the article's Creative Commons licence and your intended use is not permitted by statutory regulation or exceeds the permitted use, you will need to obtain permission directly from the copyright holder. To view a copy of this licence, visit http://creativecommons.org/licenses/by/4.0/.

\section{References}

Atolia, M., Loungani, P., Marquis, M., \& Papageorgiou, C. (2020). Rethinking development policy: What remains of structural transformation? World Development, 128, 104834. https://doi.org/10.1016/j. worlddev.2019.104834

Bennich, T., \& Belyazid, S. (2017). The route to sustainability-prospects and challenges of the bio-based economy. Sustainability, 9(6), 887. https://doi.org/10.3390/su9060887

Bringezu, S., Distelkamp, M., Lutz, C., Wimmer, F., Schaldach, R., Hennenberg, K. J., et al. (2021). Environmental and socioeconomic footprints of the German bioeconomy. Nature Sustainability. https://doi. org/10.1038/s41893-021-00725-3

Bugge, M., Hansen, T., \& Klitkou, A. (2016). What Is the bioeconomy? A review of the literature. Sustainability, 8(7), 691. https://doi.org/10.3390/su8070691 
Centre for Industrial Study, \& Cresme Ricerche. (2017). Cross-border trade for construction products. Contract No. SI2.742368 - 30-CE-0830342/00-12. Volume III-Annexes (pp. 117): Prepared for the European Commission, Directorate-General for Internal Market, Industry, Entrepreneurship and SMEs.

Cingiz, K., Gonzalez-Hermoso, H., Heijman, W., \& Wesseler, J. H. H. (2021). A cross-country measurement of the EU bioeconomy: An input-output approach. Sustainability, 13(6), 3033.

Ciriminna, R., Lomeli-Rodriguez, M., Cara, P. D., Lopez-Sanchez, J. A., \& Pagliaro, M. (2014). Limonene: A versatile chemical of the bioeconomy. Chemical Communications, 50(97), 15288-15296. https://doi. org/10.1039/c4cc06147k

Confente, I., Scarpi, D., \& Russo, I. (2020). Marketing a new generation of bio-plastics products for a circular economy: The role of green self-identity, self-congruity, and perceived value. Journal of Business Research, 112, 431-439. https://doi.org/10.1016/j.jbusres.2019.10.030

D’Amato, D., Droste, N., Allen, B., Kettunen, M., Lähtinen, K., Korhonen, J., et al. (2017). Green, circular, bio economy: A comparative analysis of sustainability avenues. Journal of Cleaner Production, 168, 716-734. https://doi.org/10.1016/j.jclepro.2017.09.053

de Vries, G., Timmer, M., \& de Vries, K. (2015). Structural transformation in Africa: Static gains, dynamic losses. The Journal of Development Studies, 51(6), 674-688. https://doi.org/10.1080/00220388.2014. 997222

Dobrzanski, P., \& Grabowski, W. (2019). Structural and productivity changes of Central and Eastern Europe. Proceedings of Rijeka Faculty of Economics: Journal of Economics and Business, 37(2), 427-471.

Efken, J., Dirksmeyer, W., Kreins, P., \& Knecht, M. (2016). Measuring the importance of the bioeconomy in Germany: Concept and illustration. NJAS-Wageningen Journal of Life Sciences, 77, 9-17. https://doi. org/10.1016/j.njas.2016.03.008

Erumban, A. A., Das, D. K., Aggarwal, S., \& Das, P. C. (2019). Structural change and economic growth in India. Structural Change and Economic Dynamics, 51, 186-202. https://doi.org/10.1016/j.strueco. 2019.07.006

European Court of Auditors. (2017). The Commission's intervention in the Greek financial crisis (pp. 130). Luxembourg: European Union.

European Union. (2020). Regulation (EU) 2020/852 of the European Parliament and of the Council of 18 June 2020 on the establishment of a framework to facilitate sustainable investment, and amending Regulation (EU) 2019/2088. Official Journal of the European Union, L 198/113-L 198/143.

Eurostat. (2008). NACE Rev. 2 Statistical classification of economic activities in the European Community. Eurostat methodologies and Working papers (pp. 367). Luxembourg, Luxembourg.

Eurostat. (2020a). Annual detailed enterprise statistics for construction (NACE Rev. 2, F) (sbs_na_con_r2). https://appsso.eurostat.ec.europa.eu/nui/show.do?dataset=sbs_na_con_r2\&lang=en.

Eurostat. (2020b). Annual detailed enterprise statistics for industry (NACE Rev. 2, B-E) (sbs_na_ind_r2). http://appsso.eurostat.ec.europa.eu/nui/show.do?dataset=sbs_na_ind_r2\&lang=en.

Eurostat. (2020c). Complete energy balances (nrg_bal_c). https://appsso.eurostat.ec.europa.eu/nui/show.do? dataset=nrg_bal_c\&lang=en.

Eurostat. (2020d). Generation of waste by waste category, hazardousness and NACE Rev. 2 activity (env_ wasgen). https://appsso.eurostat.ec.europa.eu/nui/show.do?dataset=env_wasgen\&lang=en.

Eurostat. (2020e). National accounts aggregates by industry (up to NACE A*64) (nama_10_a64). https:// appsso.eurostat.ec.europa.eu/nui/show.do?dataset=nama_10_a64\&lang=en.

Eurostat. (2020f). National accounts employment data by industry (up to NACE A*64) (nama_10_a64_e). https://appsso.eurostat.ec.europa.eu/nui/show.do?dataset=nama_10_a64_e\&lang=en.

Eurostat. (2020g). Statistics on the production of manufactured goods (prom DS-066341). https://appsso. eurostat.ec.europa.eu/nui/show.do?dataset=DS-066341\&lang=en.

Eurostat. (2020h). Treatment of waste by waste category, hazardousness and waste management operations (env_wastrt). https://appsso.eurostat.ec.europa.eu/nui/show.do?dataset=env_wastrt\&lang=en.

Fagerberg, J. (2000). Technological progress, structural change and productivity growth: A comparative study. Structural Change and Economic Dynamics, 11(4), 393-411. https://doi.org/10.1016/S0954349X(00)00025-4

European Commission. (2018). COM(2018) 673 final. Communication from the Commission to the European Parliament, the Council, the European Economic and Social Committee and the committee of the Regions. A sustainable bioeconomy for Europe: strengthening the connection between economy, society and the environment. Updated Bioeconomy Strategy Official Journal of the European Union(ISBN 978-92-79-94144-3), 107. https://doi.org/10.2777/792130.

Folke, C., Biggs, R., Norström, A. V., Reyers, B., \& Rockström, J. (2016). Social-ecological resilience and biosphere-based sustainability science. Ecology and Society, 21(3). https://doi.org/10.5751/ es-08748-210341. 
Gatto, F., \& Re, I. (2021). Circular bioeconomy business models to overcome the valley of death. A systematic statistical analysis of studies and projects in emerging bio-based technologies and trends linked to the SME instrument support. Sustainability, 13(4), 1899.

Griggs, D., Stafford-Smith, M., Gaffney, O., Rockström, J., Öhman, M. C., Shyamsundar, P., et al. (2013). Sustainable development goals for people and planet. Nature, 495(7441), 305-307. https://doi.org/10. 1038/495305a

Havlik, P. (2015). Patterns of structural change in the new EU member states. DANUBE: Law, Economics and Social Issues Review, 6(3), 133-157.

Heijman, W. (2016). How big is the bio-business? Notes on measuring the size of the Dutch bio-economy. NJAS_Wageningen Journal of Life Sciences, 77, 5-8. https://doi.org/10.1016/j.njas.2016.03.004

International Advisory Council on Global Bioeconomy. (2020). Global Bioeconomy Policy Report (IV): A decade of bioeconomy policy development around the world (p. 166). International Advisory Council on Global Bioeconomy.

Iost, S., Labonte, N., Banse, M., Geng, N., Jochem, D., Schweinle, J., et al. (2019). German bioeconomy: Economic importance and concept of measurement. German Journal of Agricultural Economics, 68(4), 275-288.

Iost, S., \& Weimar, H. (2020). Chapter 2.5 bio-based shares of sectors. In Setting up a bioeconomy monitoring: Resource base and sustainability. Thünen Working Paper 149 (pp. 80-94). Hamburg, Germany: Thünen.

Kardung, M., Cingiz, K., Costenoble, O., Delahaye, R., Heijman, W., Lovrić, M., et al. (2021). Development of the circular bioeconomy: Drivers and Indicators. Sustainability, 13(1), 413. https://doi.org/10.3390/ su13010413

Kardung, M., Costenoble, O., Dammer, L., Delahaye, R., Lovric, M., van Leeuwen, M., et al. (2019). Framework for measuring the size and development of the bioeconomy. BioMonitor deliverable 1.1. (p. 70): BioMonitor project. European Union's Horizon 2020 research and innovation programme under grant agreement No. 773297.

Kuosmanen, T., Kuosmanen, N., El Meligi, A., Tevecia, R., Gurria Albusac, P., Iost, S., et al. (2020). How big is the bioeconomy? Reflections from an economic perspective. EUR 30167 EN. (Publications Office of the European Union ed., Vol. SBN 978-92-76-17858-3, p. 49). Luxembourg: JRC.

Kuusk, A., Staehr, K., \& Varblane, U. (2017). Sectoral change and labour productivity growth during boom, bust and recovery in Central and Eastern Europe. Economic Change and Restructuring, 50(1), 21-43. https://doi.org/10.1007/s10644-016-9180-3

Liobikiene, G., Balezentis, T., Streimikiene, D., \& Chen, X. (2019). Evaluation of bioeconomy in the context of strong sustainability. Sustainable Development, 27(5), 955-964. https://doi.org/10.1002/ sd. 1984

Liobikiene, G., Chen, X., Streimikiene, D., \& Balezentis, T. (2020). The trends in bioeconomy development in the European Union: Exploiting capacity and productivity measures based on the land footprint approach. Land Use Policy, 91, 104375. https://doi.org/10.1016/j.landusepol.2019.104375

Luke. (2019). The principles for monitoring the bioeconomy (p. 4). https://www.luke.fi/wp-content/ uploads/2019/10/principles-for-monitoring.pdf: Luke-Natural Resources Institute Finland.

Lusser, M., Sanchez Lopez, J., Landa, L., Avraamides, M., Motola, V., Zika, E., et al. (2018). Joint survey on bioeconomy policy developments in different countries. Brussels \& Ispra: European Commission.

M'Barek, R., Parisi, C., \& Ronzon, T. (2018). Getting (some) numbers right-derived economic indicators for the bioeconomy.

McMillan, M., \& Rodrik, D. (2011). Globalization, structural change, and productivity growth. In M. Bacchetta, \& M. Jansen (Eds.), Making globalization socially sustainable (pp. 49:84): International Labour Organization and World Trade Organization.

McMillan, M., Rodrik, D., \& Sepúlveda, C. (2017). Structural change, fundamentals, and growth: A framework and case studies. Policy Research Working Paper 8041 (p. 40). Washington, D.C.: World Bank Group.

Meesters, K. P. H., van Dam, J. E. G., \& Bos, H. L. (2013). Protocol for monitoring of material streams in the biobased economy (p. 55). Wageningen, The Netherlands: Wageningen UR Food \& Biobased Research.

Meyer, R. (2017). Bioeconomy strategies: Contexts, visions, guiding implementation principles and resulting debates. Sustainability, 9(6), 1031. https://doi.org/10.3390/su9061031

Moussir, C.-E., \& Chatri, A. (2020). Structural change and labour productivity growth in Morocco. Structural Change and Economic Dynamics, 53, 353-358. https://doi.org/10.1016/j.strueco.2019.06.005

Neumayer, E. (2003). Weak versus strong sustainability: Exploring the limits of two opposing paradigms. Edward Elgar Publishing. 
European Commission. (2012). COM(2012) 60 final. Communication from the Commission to the European Parliament, the Council, the European Economic and Social Committee and the committee of the Regions. Innovating for Sustainable Growth: A Bioeconomy for Europe. Official Journal of the European Union, 9. https://ec.europa.eu/research/bioeconomy/pdf/official-strategy_en.pdf.

Pellerin, W., \& Taylor, D. W. (2008). Measuring the biobased economy: A Canadian perspective. Industrial Biotechnology, 4(4), 363-366. https://doi.org/10.1089/ind.2008.4.363

Peneder, M. (2003). Industrial structure and aggregate growth. Structural Change and Economic Dynamics, 14(4), 427-448. https://doi.org/10.1016/S0954-349X(02)00052-8

Piotrowski, S., Verkerk, H., Lovric, M., Ronzon, T., Parisi, C., Philippidis, G., et al. (2018). Status quo of data collection methodologies on bioeconomy and recommendations. BioMonitor deliverable 3.1 (p. 37): BioMonitor project. European Union's Horizon 2020 research and innovation programme under grant agreement No. 773297.

Porc, O., Hark, N., Carus, M., Dammer, L., \& Carrez, D. (2020). European Bioeconomy in Figures 2008-2017 (p. 28): Nova-Institut, BIC.

Ramcilovic-Suominen, S., \& Pülzl, H. (2018). Sustainable development-A 'selling point' of the emerging EU bioeconomy policy framework? Journal of Cleaner Production, 172, 4170-4180. https:// doi.org/10.1016/j.jclepro.2016.12.157

Robert, N., Giuntoli, J., Araujo, R., Avraamides, M., Balzi, E., Barredo, J. I., et al. (2020a). Development of a bioeconomy monitoring framework for the European Union: An integrative and collaborative approach. New Biotechnology, 59, 10-19. https://doi.org/10.1016/j.nbt.2020.06.001

Robert, N., Jonsson, R., Chudy, R., \& Camia, A. (2020b). The EU bioeconomy: Supporting an employment shift downstream in the wood-based value chains? Sustainability, 12(3), 758. https://doi.org/ $10.3390 / \mathrm{su} 12030758$

Rockström, J., Steffen, W., Noone, K., Persson, Å., Chapin, F. S., Lambin, E. F., et al. (2009). A safe operating space for humanity. Nature, 461(7263), 472-475. https://doi.org/10.1038/461472a

Rodríguez-Pose, A., \& Ganau, R. (2019). Institutions \& the productivity challenge for European Regions. 2019 Fellowship Initiative Papers 116 (p. 36). Luxembourg.

Ronzon, T., Piotrowski, S., Tamosiunas, S., Dammer, L., Carus, M., \& M'barek, R. . (2020). Developments of economic growth and employment in bioeconomy sectors across the EU. Sustainability, 12(11), 4507. https://doi.org/10.3390/su12114507

Sijtsema, S. J., Onwezen, M. C., Reinders, M. J., Dagevos, H., Partanen, A., \& Meeusen, M. (2016). Consumer perception of bio-based products - an exploratory study in 5 European countries. NJAS - Wageningen Journal of Life Sciences, 77, 61-69. https://doi.org/10.1016/j.njas.2016.03.007

Solow, R. M. (1957). Technical change and the aggregate production function. The Review of Economics and Statistics, 39(3), 312-320.

Steffen, W., Richardson, K., Rockström, J., Cornell, S. E., Fetzer, I., Bennett, E. M., et al. (2015). Planetary boundaries: Guiding human development on a changing planet. Science, 347(6223), 1259855. https:// doi.org/10.1126/science. 1259855

Timmer, M. P., \& Szirmai, A. (2000). Productivity growth in Asian manufacturing: The structural bonus hypothesis examined. Structural Change and Economic Dynamics, 11(4), 371-392. https://doi.org/10. 1016/S0954-349X(00)00023-0

Vandermeulen, V., Prins, W., Nolte, S., \& Van Huylenbroeck, G. (2011). How to measure the size of a biobased economy: Evidence from Flanders. Biomass and Bioenergy, 35(10), 4368-4375. https://doi.org/ 10.1016/j.biombioe.2011.08.007

Wesseler, J., \& von Braun, J. (2017). Measuring the bioeconomy: Economics and policies. Annual Review of Resource Economics, 9, 275-298. https://doi.org/10.1146/annurev-resource-100516-053701

Publisher's Note Springer Nature remains neutral with regard to jurisdictional claims in published maps and institutional affiliations. 